\title{
A PETŐ-MÓDSZER HALADÓ SZEMLÉLETÉNEK MEGVILÁGÍTÁSA A KONSTRUKTÍV PEDAGÓGIA KRITÉRIUMAI ALAPJÁN
}

\section{Szerzők:}

Oravecz Adrienn

Eszterházy Károly Egyetem (Magyarország)

Első szerző e-mail címe:

ora_adri@msn.com.com
Lektorok:

Dr. Estefánné dr. Varga Magdolna

Eszterházy Károly Egyetem

(Magyarország)

Dr. habil. Réthy Endréné

Kodolányi János Főiskola (Magyarország)

Oravecz Adrienn (2018): A Pető-módszer haladó szemléletének megvilágítása a konstruktív pedagógia kritériumai alapján. Különleges Bánásmód, IV. évf. 2018/3 szám, 93-100. DOI 10.18458/KB.2018.3.93

\begin{abstract}
Absztrakt
Jelen tanulmány Dr. Petö András módszerét ismerteti és annak haladó, korát megelözö szemléletét mutatja be a konstruktiv pedagógia kritériumai alapján. A tanulmányban hangsúlyos szerepet kap a csoportban történö fejlesztés, a társas tanulás, amely a neveltek későbbi óvodai és iskolai közösségekbe való hatékony beilleszkedését segíti elö. A közös rehabilitációs alkalmak motiválólag hatnak az egyénre és csoportra egyaránt. A mü ismerteti továbbá a motivációért felelös agyi folyamatokat is. Végezetül a tanulmány érinti a konstruktiv életvezetés területeit és az egyes területekhez kapcsolódó a jövőben még megoldásra váró feladatokat is, a mozgássérültek integrációjával kapcsolatban.
\end{abstract}

Kulcsszavak: Pető módszer, konstruktívizmus, motiváció, integráció

Diszciplina: gyógypedagógia, neurológia

\begin{abstract}
The study describes the Petö Method based on the principles of Constructive Pedagogy. The study focuses on the importance of the rehabilitation group because of two reasons: Firstly, it helps to children to integrate into the mainstream basic and secondary education later successfully. Secondly, the common goal and the feeling of togetherness has a great motivation effect on the individuals as well as the members of the group. Therefore the study also highlights the neurological aspects of motivation. Last but not least, the areas of constructive lifestyle is being reported and those tasks that needs to be solved in the near future to make the inclusion process even more effective for people with motor disabilities.
\end{abstract}

Keywords: Pető Method, constructivism, motivation, integration

Disciplines: special pedagogy, neurology 


\section{A Pető módszer konstruktivista jegyei}

A tanulmány célja a konduktív pedagógia bemutatása konstruktivista szemszögből. A konduktív pedagógia a pedagógia egy speciális ága, amely az alternatív rehabilitációs eljárások közé tartozik. „Pető a történelem egy olyan korszakában és helyszínén kezdte megalkotni rendszerét és elméletét, amely fogékony volt a reformgondolatokra és reformgyakorlatokra, de egy olyan rendszerben és országban fejezte be azt, amely diktatórikus viszonyai folytán nem kedvezett az alternatív tudományfelfogásnak vagy pedagógiai praxisnak. Hogy az évtizedekig fennálló totális hatalmi rendszerben mégis életben maradhatott a konduktív nevelés, ma már látható, hogy nagyrészt Pető szerteágazó személyes és szakmai kapcsolatainak, s persze hihetetlen elszántságának volt köszönhető" (Földesi, 2014, 303. o.). Petőre nagy hatással volt a századelö Bécse, amely bölcsője volt a legújabb pszichológiai áramlatoknak, amelyek holisztikusan a test és a lélek egységeként szemlélték az embert, a természetes gyógymódoknak, mint például a homeopátiás orvoslás. 1922-ben Semmeringben dolgozva fordult érdeklődése azon gyerekek és felnőttek felé, akik szültésük óta mozgáskorlátozottak. Akkoriban a központi idegrendszeri sérülés következtében mozgáskorlátozottá vált egyéneknek az állapotát a medicina eszközeivel próbálták javítani. A legsúlyosabb állapotúakat elfekvőkben helyezték el és meg sem próbálták rehabilitálni őket.

Pető felfogása szerint a mozgássérülésekért a különbözö funkciók összhangjának hiánya, az idegrendszer sérült, vagy hiányos müködése a felelös. A konduktív nevelés alapeszméje, hogy az idegrendszer a sérülések ellenére is rendelkezik tartalékokkal, kihasználatlan kapacitással, új kapcsolatok kiépülésének a lehetőségével, amelyek a tanulási-tanítási folyamat megfelelő irányításával mozgósíthatók. A tanulási-tanítási folyamatban azokra jellegzetes emberi tulajdonságokra épít, amelyek még súlyos idegrendszeri károsodás esetén is megvannak. Ilyen alapvető tulajdonság például a kreativitás. „Önmagából és a környezetéböl kiindulva felépíti a valóságképét, de az a valóságnak nem pontos lenyomata, másolata lesz, hanem egy olyan új sajátosan alkotott, koherens, egész kép a tudatban, ami eltérhet attól, amit az egyén megtanult" (Balogh és Horváth, 2014,20. o.).

Az idézetben szereplő gondolat valójában nem más, mint a konstruktivista felfogás, egyik alaptétele, amely szerint ,az emberi tudás mentális konstrukció eredménye, vagyis a megismerő ember felépít magában egy világot, amely tapasztalatainak szervezője, befogadója, értelmezője lesz. Ennek a belső világnak, világmodellnek nagyon fontos funkciója a megismerő embert érő információk feldolgozása, értelmezése, rendszerbe való beépítése. Ez pedig nem más, mint a tanulás. A tanulás tehát egy állandóan müködő konstruáló tevékenység, a belső világ folyamatos építése" (Pálvölgyi, 2009, 136. o.). A konduktív pedagógia megtanítja újra konstruálni a rossz idegrendszeri müködés következtében jelentkező patológiás reflexeket, amelyek a hiányos, vagy a nem megfelelő mozgásokért felelősek. Lényeges a tanuló aktív részvétele a tanulási folyamatban, a „konduktor tanító pedig az pedagógus, akinek a segítségével a tanítvány maga épít fel célszerü cselekedeteket" (Balogh és Horváth, 2014, 22. o.). A konstruktivista pedagógia csakúgy, mint a konduktív pedagógia nagy szerepet tulajdonít az aktív tanulásnak és az egyéni célképzésnek. Karagiorgi és Symeou (2005) kiemelik ennek fontosságát, mely szerint értelmező, jelentőségteljes tanulás akkor jelentkezik, ha tanulókban kifejlödik egy hatékony problémamegoldási képesség. Véleményük szerint hagyni kell a tanítványokat, hogy saját maguk oldják meg az adott feladatot, mert ez motiválólag hat rájuk, és elégedettséggel tölti el őket, ha végül sikerrel vették az akadályokat. A sikerrel kivitelezett feladatmegoldásnak köszönhetően nő az önbizalmuk. 


\section{A motiváció szerepe a mozgássérülteknél és motiváció neurológiai alapjai}

A mozgássérülteknél még fontosabb szerepe van a motivációnak, mint egészséges társaik esetében, mert alacsonyabb az önbecsülésük. Pető jól tudta azt, hogy ezeknek a gyerekeknek nagy szükségük van a sikerélményre, hogy ez motiválja őket a továbbfejlődésben, ezt úgy teremtette meg számukra, hogy rendszeresen bemutatót szervezett. Itt mindig egy-egy csoport kapott lehetőséget, hogy megmutassa mennyit fejlödött. (Oravecz, 2015,) A csoportos bemutatók révén Pető megvalósította a motiváció valamennyi ismert fajtáját, amelyeket Réthy (2015) a következöképp összegzett: internalizált életcélok, intrinzik késztetés, tevékenység, mint autonóm motiváció, szociális elköteleződés, extrinzik kontrolált motiváció. Az internalizált életcélok olyan célok összessége, amit saját belső elhatározásból tesz a személy. Az intrinzik késztetés másképp belső motivációt jelent. A belső motivációt az különbözteti meg a külső, azaz extrinzik motivációtól, hogy itt maga a tevékenység az örömforrása és nem a tevékenységért járó elismerés, jutalom. A csoporton belül minden tagnak a napi saját életcéljára kell összpontosítania, de csoporttársai felé is elköteleződéssel tartozik, hogy harmonikus egységet alkotva létrejöhessen a csoport közös aznapra kitüzött célja. Az extrinzik motivációt a konduktortól kapott elismerés adja.

A csoportban történő mozgásfejlesztés nagyszerü keretet biztosít a kollaboratív tanulásnak. A konstruktivista tanuláselmélet szintén előnyben részesít minden közösségben történő nevelést. „Az együttmüködést, a közösségi kreativitást, a gazdag csoportfolyamatokat, a szerepek kidolgozását és gyakorlását lehetővé tevő közösségi nevelésről van itt szó, amely optimális környezetet teremthet a gyerekekben zajló konstrukciós folyamatok számára" (Nahalka, 2002, 92. o.). A viselkedésszabályozás megtanulása miatt is nagyon lényeges a csoportos együttlét. Stimulusnak nevezzük a környezetnek azon tényezőjét, amely a viselkedésre valamilyen hatással van. Az ember viselkedését befolyásolja a környezete, bizonyos biológiai tényezők, és a nyelvi szabályozás törvényszerüségei. A viselkedés által a környezetben elöidézett változások nemcsak az adott viselkedéstől, de az aktuális környezet minőségétől is függenek. Ezt a környezeti hatást hívják kontingenciának. Szociális kontingencia az, amikor a környezetünkben lévő emberek miatt módosul a viselkedés. A nyelvi viselkedés eredendő célja, hogy az ember képes legyen felülemelkedni az aktuális környezeti hatásokon és azt tegye, ami a jól felfogott érdekét szolgálja. Ez a funkció testesül meg az akaraterőben, amely a nyelvi viselkedés egyéni viselkedés levetülésének tekinthető. Az akaraterö tágabb környezetében találhatók azok a normák, szabályok, amelyek mind az egyén mind a közösség hosszabb távú céljait szolgálják (Lajkó és Barabás, 2010,).

Mivel a konduktív pedagógia az egyén mozgásállapotának javítása érdekében a csoportban történő tanulás révén törekszik a központi idegrendszer befolyásolására, ezért fontos, hogy szót ejtsünk azokról az agyi folyamatokról, amelyek felelösek a motivációért és a kooperációért. Ennek érdekében a következőkben a motiváció jelensége kifejezetten az ideglélektan oldaláról kerül megvilágításra. Deák (2011) ismerteti az agy motivációért felelős területeit. Kiemeli, hogy a motivációban a köztiagynak kitüntetett szerepe van, hiszen ott található a hipotalamusz. A hipotalamusz szabályozza az un. elsődleges drive-ok müködését. Ezen az agyterületen két ellentétes folyamat megy végbe. Az egyik folyamat gátlólag, míg a másik serkentőn hathat a viselkedésre. A limbikus rendszer kiterjedt agyterületeket foglal magában, melyek elsősorban a féltekék mediális részén, zömében a temporális lebeny területén találhatók. Ez a rész kapcsolatban áll az érzékelő idegpályákkal és az agytörzzsel is. Itt történik a beérkező ingerek „minősítése”, érzelmi színezetű értékelése. Azt, hogy mennyire vagyunk motiváltak, és hogy milyen érzelmek társulnak az adott cselekvés végrehajtásához azt a limbikus rendszertől kapott visszajelzések döntően befolyásolják, ez kihat arra is, hogy esetleg máskor is kedvvel ismételjük-e meg az adott cselekvést, vagy sem. Úgy is fogalmazhatnánk, hogy a limbikus rendszer agyunk „pedagógusa”, mivel értékel és minősít. A fejlettebb agykérgi részeknek, valamint a hormonális és a vegetatív idegrendszeri 
tényezöknek is szerepük van a motivációban. Az egyéni motiváció nagyon fontos, ám talán még a személyes motivációnál is lényegesebb, hogy képesek legyünk szükebb és tágabb szociális környezetünkben kooperálni másokkal, hiszen legtöbbször mások hatékony közremüködésére is szükség van, hogy elérjük személyes céljainkat. Benedek és Braunitzer (2010) végzett neurológiai vizsgálatában elemezte a motivált viselkedések közül a kooperatív viselkedési formákat. A kooperatív sprektum az egyén viselkedésrepertoárjáért felelős, amely az ellenségeskedéstöl a kooperációig terjed. Az 1. ábra a kooperatív sprektumot alkotó viselkedésmintázatok kifejeződésének alapvető részfolyamatait ábrázolja neurológiai vizsgálatok alapján.

1. ábra: A kooperativ viselkedés mintázatai (forrás: Benedek és Braunitzer, 2010, 34. o.)

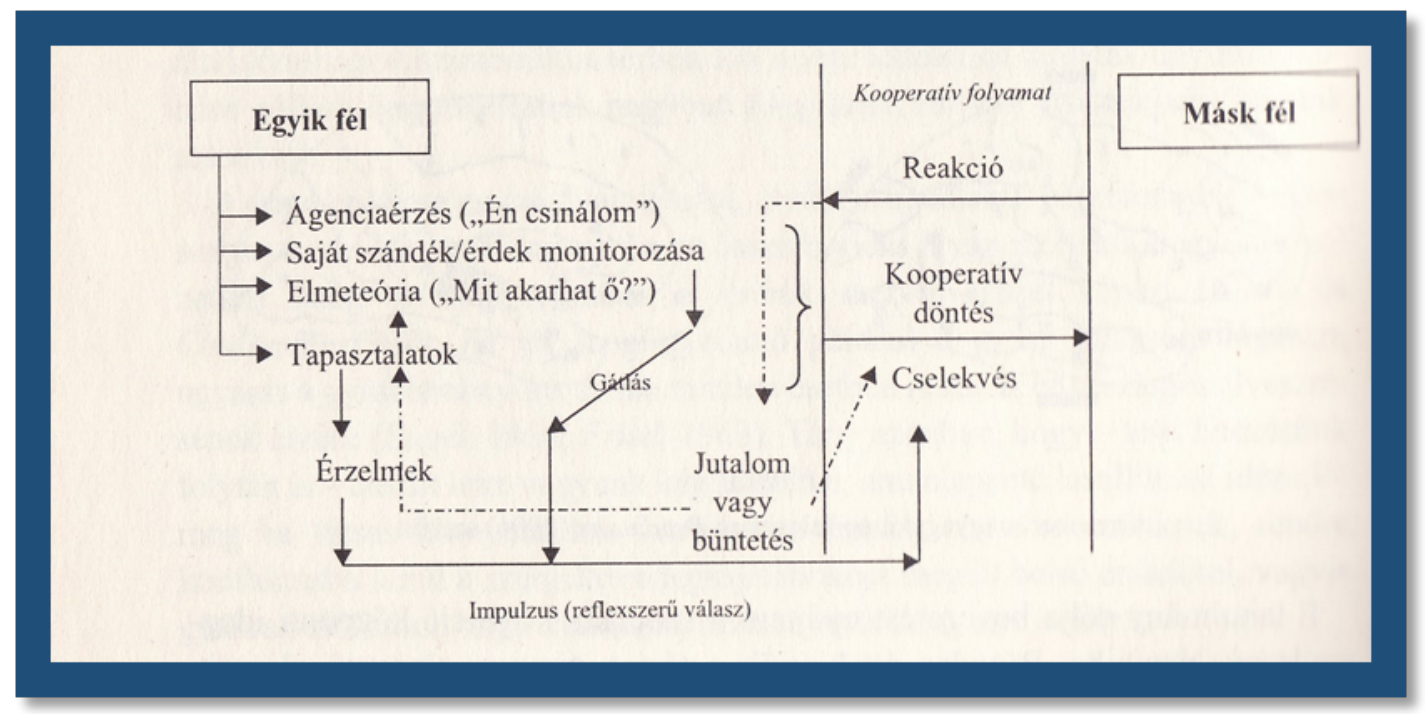

Benedek és Braunitzer (2010) alapján ágenciaérzésnek nevezzük, ha az interakcióban lévő felek cselekedeteiket önmaguktól származóként azonosítják, amely a munkamemória prefrontális agykérgi rendszerein keresztül valósul meg. Ezek a területek felelnek az agresszív, vagy kooperatív válaszok helyzetnek megfelelő adekvát módon történő gátlásáért is. A folyamatban fontos hogy mennyire ismerjük a partner szándékait, reakcióit, azaz rendelkezünk-e az elmeteória, vagy mentalizáció képességével. A munkamemória az információk fenntartása miatt fontos, még a multiszenzoros integráció a komplex környezet monitorizálására szolgálhat annak érdekében, hogy az információ a célcsoporttal összevethető legyen. A motivált kooperatív viselkedés kialakulása hosszú folyamat.

A csecsemők a kellemes ingereket keresik, a kellemetlenséget okozó ingereket kerülik, de fejlődésünk során egyre inkább képessé válunk reakcióink késleltetésére, amelyhez elengedhetetlen a vegetatív idegrendszer, limbikus rendszer, hipotalamusz-hipofázismellékvese tengely, valamint a frontális-prefrontális kéregrészek összjátéka. A hipotalamusz, a központi idegrendszer koordinátora, ha a testből érkező jelzések indokolttá teszik, a hipofizisen keresztül hormonálisan aktivizálja a mellékveséket és kiváltódik a stresszreakció. A félelemérzésért az amygdala a felelős, amely veszélydetektorként müködik. A szeparációs szorongás 10 hónapos korban jelenik meg. A kötődés hiánya nagyon káros a korai életkorban 
az idegrendszerre, mert krónikus stresszként hathat, ami miatt a hippokampusz glükokortikoidban gazdag receptorai felfokozottan müködnek, ennek következtében a fejlődésben jelentős visszamaradottság tapasztalható. Továbbá a szociális izoláció következtében az impulzusszabályzásért felelös frontális kérgi területek nem tudnak megfelelően bejáratódni, ami tanulási nehézséget, és rossz vagy csökkent szociális funkciót okoz.

A társas interakcióban maga a társ és a nekünk szentelt figyelme a jutalom. Megvannak az agy jutalmazásért felelős részei, ezek a következők: a hippokampusz, amelynek általános társas tanulási funkciója van, az agytörzs ventralis tegmenuma, amely a partner jutalomértékének kialakításáért felel. Végül, de nem utolsó sorban a nucleus accumbensstriatum, amely kiegészíti a frontális kéreg kognitív szabályalkotó funkcióját emocionálisan. A fentebb már idézett Benedek és Braunitzer (2010) nyomán az itt végbemenő dopamin felszabadulás segít többek közt az új viselkedések elsajátításában.

\section{A szociális életképesség komponensei: egészségmegőrzés, élethosszig tartó tanulás, munkába állás jelentősége a mozgássérülteknél}

Munkámban azért hangsúlyoztam ki ennyire a kortárscsoportban történő fejlesztést, mert ez előkészíti a neveltek tágabb szociális közösségekbe (óvodai és iskolai közösségekbe) történő sikeres integrációját. Pető már a kezdetek kezdetén szociálisan életképessé akarta tenni a rábízott személyeket, megtanítani őket a „konstruktív életvezetésre, vagyis arra, hogy szociálisan értékes, de egyénileg is eredményesek" legyenek (Bábosik, 2004, 13. o.). Bábosik (2011) három feltételt említ a szociális életképesség szempontjából: a munkavilágára való felkészülést, az élethosszig tartó tanulást, illetve az egészségmegőrzést.

Az egészségtudatos életvitel az egészségmegőrzés: jellemzően a neveltek rendszeresen részt vesznek a normál iskolai testnevelés órán, amellett, hogy természetesen megkapják a speciális szükségletüknek megfelelö fejlesztést is. A mozgássérültek esetében még nagyobb jelentősége van a mozgás megszerettetésének és az egészséges táplálkozásnak, mert ha elhíznak, az rohamosan rontja az állapotukat, beszükül a mozgástartományuk és fokozódik az ízületek kopása. A rendszeres sportolás nemcsak az állapotmegőrzésben segít, de életük más területére is kedvezően hat. Segítheti őket a beilleszkedésben, baráti kapcsolatok kialakításában és a megküzdésben. A mozgás fiziológiás szempontú hatásai a következők: javítja a szív-és keringési rendszer müködését (az erek rugalmasabbá válnak és a szívizmok is stabilabbak lesznek), továbbá a pulzusszám is lecsökken; a légzőrendszer oxigénfelvevő képessége nő; javul a mozgáskoordináció; jótékonyan hat az idegrendszerre és az immunrendszerre; valamint a megfelelő testsúlyelérésében és megtartásában is segít, stb. (Lénárt, 2002, Gyömbér és Kovács, 2012,) A sok pozitív élettani hatás közül leginkább fontos kiemelnünk a légzőrendszerre gyakorolt hatását, gyakori főleg a spasztikusoknál, hogy a feszes állapot nemcsak a végtagokat érinti, de a légzőszervekben is jelentkezhet, amelynek következménye a normálisnál jóval gyakoribb levegővétel. Izgalmi állapotban ez hatványozottan jelentkezik, eredménye erős zihálás és kifulladás. A rendszeresen végzett sporttevékenység segíthet a helyes légzéstechnika elsajátításában is. A Petö Intézet kiemelt feladatának tekinti a sportban tehetséges fiatalok támogatását, ezért 2010 májusában létrejött a Pető Sport Egyesület. A Pető Intézet mozgássérült diákjainak, neveltjeinek alkottak egy sportolást segítő, a mozgássérültek sportját támogató szervezetet. Az egyesület célja, hogy az egészséges és sportértékű testmozgást rendszeressé tegye a diákoknak, és elindítsák őket az általuk támogatott versenysportokban, paraolimpiai sportágakban.

Munka világára való felkészülés: a jó fizikum nélkülözhetetlen a napi munkavégzéshez, hogy az illető személy meg tudja tenni az otthona és munkahelye, vagy oktatási intézménye 
közötti távolságot. Móré és Mező (2016) ismerteti a fogyatékosok hazai közoktatási és közfoglalkoztatási helyzetét. A statisztikai adatokból egyértelmüen kitünik, hogy lassú növekedés tapasztalható a fogyatékos személyek foglalkoztatása tekintetében (köszönhetően a törvényi szabályozásnak, amely például kedvezményeket biztosít a megváltozott munkaképességü egyéneket foglalkoztató munkahelyeknek). Ezt a célt szolgálja például a Fogyatékos-barát Munkahelyek embléma is. A díjat 2010 óta közösen adja át az Emberi Erőforrások Minisztériuma az American Chamber of Commerce in Hungary, a Szövetség a Kiválóságért Közhasznú Egyesület és a Salva Vita Alapítvány. Az elismerés elnyeréséért a pályázóknak be kell mutatniuk egy rövid távú 3 hónapos és egy középtávú 2 éves időtartalmú fejlesztést. Szigorú minősítési szempontoknak kell megfelelniük, ami eleget tesz az Európai Minőségmenedzsment Alapítvány (EFQM) Kiválóság Modellje alapján kidolgozott koncepciónak. Ha ezen a szigorú rostán átestek, két évig birtokolhatják az emblémát.(Net1).

Az élethosszig tartó tanulás: A lifelong learning koncepciója különösen hazánk Európai Uniós csatlakozása óta van a köztudatban és hatja át mindennapi életünk számos területét, különösen az oktatást és a munkaeröpiacot. Az élethosszig tartó tanulás nem takar mást, mint az egyéni képességek és készségek folyamatos fejlesztését. Mező (2013) szerint kreatív, azaz produktív tanulásról csak akkor beszélhetünk, ha megvalósul az információk kreatív módon történő gyüjtése és feldolgozása, vagyis a tanuló sokkal több tudással gazdagodik a tanulási folyamat révén. Mivel ennyire előtérbe került, hogy tanulás által az ember egyre jobb és jobb lehet, ez kedvezően hatott a fogyatékosok beiskolázására is a többségi iskolákba, egyre több iskola fogadja öket szívesen, hiszen a kreatív tanulás elmélete nem a hiányosságokra fókuszál, hanem a személyben megbúvó kiaknázatlan kreatív potenciálra.

\section{Megoldásra váró feladatok a sikeresebb társadalmi el- és befogadásért}

Ha csak a puszta statisztikát nézzük, az valóban bizakodásra ad okot, de ezzel szemben a valóság még sajnos mindig az, hogy sem a munkáltatók, sem pedig a nevelő-oktató munkát végző pedagógusok nem elég felkészültek a fogyatékosokra. Feketéné dr. Szabó Éva 2013ban végzett felmérése szintén arra a következtetésre jutott, hogy a pedagógusok nem szívesen nyitnak a súlyosabb Cerebral Paresissel élők (továbbiakban $\mathrm{CP}$ ) irányába, ami annak is köszönhető, hogy a ,pedagógus a felkészületlenségéből adódóan alapvető tünettani ismeretek nélkül a gyermek fejlesztési programjában sem tudja kellően képviselni például a mozgáskoordinációfejlesztési igényeket, így oktatási és nevelési programjába sem tudja őket integrálni."(Feketéné Szabó, 2013, 158. o.) A jövőben megvalósításra váró feladatok közül kiemeli a többségi iskola nevelőtestületének széleskörü tájékoztatását a CP-s tünetspecifikumokra, illetve a konduktori szakma hatásköreire és kompetenciáira vonatkozóan. Osztva Feketéné véleményét, fontosnak tartjuk az általános pedagógusképzésbe a központi idegrendszeri sérültekre vonatkozó ismeretek beillesztését, továbbá a konduktív nevelésben felhalmozódott tapasztalat és tudás hasznosítását a pedagógus-továbbképzéseken.

Gondolatait kiegészítve: nem csak a pedagógusokat informálhatnák, hanem legalább ilyen fontos volna a munkáltatók tájékoztatása és felkészítése is, mert egyszer véget érnek az iskolapadban töltött évek és hiába a jó oktatás, a tanulmányi sikerek, ha az egykori nevelt a munkaeröpiacon nem állja meg a helyét, képtelen lesz az önfenntartásra. Sürgős volna az egykori időközben felnőtté lett gondozottak munka világába történő segítése, mint ahogy az már számos külföldi konduktív nevelést folytató centrum koncepciójában jelen van. Nem is beszélve a felnőttkori utógondozásról és a mozgásállapotot megőrző rehabilitációs és sporttevékenységek felkínálásáról, amely külföldön már szintén bevett gyakorlat. Akkor beszélhetünk igazán hatékony konduktív-konstruktív életvezetési modellről, ha az egy életen át tart, és nemcsak az alap és közoktatás idejére szól csupán. 


\section{Záró gondolatok}

Jelen tanulmány a Dr. Pető András által kidolgozott konduktív nevelést ismertette konstruktivista perspektívából. A kortárscsoport szerepe került a fókuszpontba, rávilágítva annak pedagógiai, pszichológiai és neurológiai jelentőségére. A tanulmány befejező része érintette a még megoldásra váró feladatokat a konduktív-konstruktív életvezetéssel kapcsolatban.

\section{Irodalom}

Balogh, E. és Horváth Dezsőné (2014). Dr. Hári Mária (1923-2001.). Budapest: Pető András Főiskola.

Bábosik, I. (2004). Neveléselmélet Nevelés az Európai Unióban. Budapest: Osiris Kiadó.

Bábosik, I., Borosán, L., Hunyady Györgyné, M. Nádasdi M. és Schaffhauser F. (2011). Pedagógia az Iskolában A szociális életképesség megalapozása. Budapest: ELTE Eötvös Kiadó.

Benedek, Gy. és Braunitzer, G. (2010). Az agressziótól a kooperációig: az együttmüködési sprektum ideglélektani alapjai In: Zsolnai A. és Kosik L.(szerk.): A szociális kompetencia fejlesztésének elméleti és gyakorlati alapjai Budapest: Nemzeti Tankönyvkiadó, 32-47.

Deák, A. (2011). A motiváció. Budapest: MPANNI

Feketéné Szabó, É. (2013). A konduktív nevelés új feladatai. In: Bábosik I. (szerk.): Az iskola optimalizálásának lehetőségei. Budapest: Eötvös József Könyvkiadó, 153-162.

Földesi, R. (2014). Pető András szellemi köre és személyes kapcsolatai. In: Németh A., Pukánszky B. és Pirka V. (szerk.): Továbbélö utópiák. Reformpedagógia és életreform a 20. század elsö felében. Budapest: Gondolat Kiadó. 302-316.

Gyömbér, N. és Kovács, K. (2012). Pici lábak a pályán, avagy a fiatalkori sport pszichológiája. In: Gyömbér N. és Kovács K. (szerk.): Fejben döl el. Sportpszichológia mindenkinek. Budapest: NORAN LIBRO, 191-220.

Karagiorgi, Y. és Symeou, L. (2005). Translating Constructivism into Instructional Design: Potential and Limitations. Educational Technology \& Society, 8. 1. sz. 17-27.

Net: http://www.ifets.info/journals/8_1/5.pdf Letöltve: 2016.01.03-án.

Lajkó, K. és Barabás, K. (2010). A viselkedésszabályzás dimenziói In: Zsolnai A. és Kosik L.(szerk.): A szociális kompetencia fejlesztésének elméleti és gyakorlati alapjai. Budapest: Nemzeti Tankönyvkiadó, 15-31.

Lénárt Á. (2002). Néhány gondolat a gyerekek sporttal kapcsolatos motivációjáról. In: Lénárt Á. (szerk): Téthelyzetben. Sportpszichológiáról edzőknek és versenyzóknek. Budapest: Országos Sportegészségügyi Intézet, 95-96.

Móré M. és Mező K. (2016). Fogyatékossággal élők a tanulástól a munkavállalásig. Különleges Bánásmód, 2. 1. sz. 17-26.

Net: http://www.hwpf.hu/kulonlegesbanasmod/archivum/kb2016-1/KB2016-1-017-E1001-5165XXXX0-Móré-Mező.pdf Letöltve: 2016. 01.03-án.

Mező K. (2013). Élethosszig tartó kreatív tanulás. In Juhász, J. és Szegedi, E. Üzenet a palackban. Budapest: Tempus Közalapítvány, 71-84. Elérhető a weben: https://issuu.com/tka_konyvtar/docs/uzenet_a_palackban_issuu_xs

Nahalka, I. (2002). Hogyan alakul ki a tudás a gyerekekben? Konstruktivizmus és pedagógia. Budapest: Nemzeti Tankönyvkiadó.

Oravecz, A. (2015). A Pető Intézet Integrációt segítő mindennapos tevékenysége itthon és külföldön, Különleges Bánásmód, 1. 4. sz. 49-64.

Net: http://www.hwpf.hu/kulonlegesbanasmod/archivum/kb2015-4/KB2015-4-049-M5000-65XXXXXX0-Oravecz.pdf Letöltve: 2016.01.02-án 
Pálvölgyi, F (2009). Az értékközpontú erkölcsi nevelés konstruktív rendszere. A szociomorális fejlesztés új szemléletủ pedagógiai koncepciója Mester és Tanítvány 2009. 21. sz. 134-150.

Net: https://btk.ppke.hu/uploads/articles/6694/file/21.pdf\#page=135 Letöltve: 2016.01.02-án.

Réthy Endréné (2015). Elégedettség, Boldogság, Jóllét tanuló tanárok körében Győr: Palatia Nyomda és Kiadó Kft.

Net1:http://www.hrportal.hu/c/ezek-a-fogyatekossag-barat-munkahelyek-20150324.html 